Jurnal Basicedu Volume 1 Nomor 1 Tahun 2017 Halaman 31-44
Research \& Learning in Elementary Education
http:// stkiptam.ac.id/indeks.php/basicedu

\title{
PENGARUH MODEL PEMBELAJARAN SINEKTIK TERHADAP KEMAMPUAN MENULIS PUISI BEBAS SISWA SEKOLAH DASAR NEGERI 55 PEKANBARU
}

\author{
Iis Aprinawati ${ }^{1}$ \\ ${ }^{1}$ Dosen Prodi PGSD Universitas Pahlawan Tuanku Tambusai \\ e-mail : aprinawatiiis@gmail.com
}

\begin{abstract}
This research was motivated due to the lacking ability of writing free poetry in elementary school. Learning literature in primary schools is very important, especially learning to write a free poetry. By learning to write poetry, the students can explore their potentials. This study was aimed to determine the effect of using the syntactic learning model towards the ability in writing free poetry. The research method used was a quasi experiment. Subjects in this study were fifth grade students of SD Negeri 55 Pekanbaru. The instrument used in this study was a test description (students' poetry writing) to test the ability in writing free poetry and after the given treatment. The treatment given to the experimental class was a syntactic learning model, while the control class was treated with direct learning. Data analysis was performed by quantitative and qualitative statistical analysis through the average different techniques test with significance level $\alpha=0.05$. The results of the study showed that the experimental class using syntactic models affects the ability of the student in writing free poetry which can be seen from the mean difference of the experimental class that used syntacticapproach and control class that used direct learning.
\end{abstract}

Keywords: Syntactic Learning Model, The Ability in Writing Free Poetry.

\begin{abstract}
Abstrak
Penelitian ini termotivasi karena kurangnya kemampuan menulis puisi di sekolah dasar. Belajar sastra di sekolah dasar sangat penting, apalagi belajar menulis puisi. Dengan belajar menulis puisi, para siswa dapat menggali potensi mereka dan mengembangkan kreativitas mereka. Penelitian ini bertujuan untuk mengetahui pengaruh penggunaan model pembelajaran sintaksis terhadap kemampuan menulis puisi bebas. Metode penelitian yang digunakan adalah percobaan kuasi. Subjek dalam penelitian ini adalah siswa kelas V SD Negeri 55 Pekanbaru. Instrumen yang digunakan dalam penelitian ini adalah deskripsi tes (penulisan puisi siswa) untuk menguji kemampuan menulis puisi bebas sebelum dan sesudah perlakuan yang diberikan. Perlakuan yang diberikan pada kelas eksperimen adalah model pembelajaran sintaksis, sedangkan kelas kontrol diobati dengan pembelajaran langsung. Analisis data dilakukan dengan analisis statistik kuantitatif dan kualitatif melalui teknik uji beda rata-rata dengan tingkat signifikansi $\alpha=0,05$. Hasil penelitian menunjukkan bahwa kelas eksperimen menggunakan model sintaksis mempengaruhi kemampuan siswa dalam menulis puisi bebas yang dapat dilihat dari rata-rata perbedaan kelas eksperimen yang menggunakan pendekatan sintaksis dan kelas kontrol yang menggunakan pembelajaran langsung.
\end{abstract}

Kata Kunci : Model Pembelajaran Sinektik, Menulis Puisi Bebas

Iis Aprinawati

Page 31

Pengaruh Model Pembelajaran Sinektik terhadap Kemampuan Menulis Puisi Bebas

Siswa Sekolah Dasar Negeri 55 Pekanbaru 


\section{PENDAHULUAN}

Pembelajaran sastra di sekolah sangat penting diajarkan, khusunya pembelajaran dalam menulis puisi bebas. Dalam pembelajaran sastra, guru harus menggali potensi, sehingga mereka mempunyai kemampuan untuk menulis puisi dengan baik. Oleh sebab itu, guru harus membina dan membimbing anak-anak didik secara maksimal agar kreativitas anak berkembang dengan potensi yang dimilikinya.

Siswa mengapresiasikan sebuah puisi bukan hanya ditujukan untuk penghayatan dan pemahaman, melainkan berpengaruh mempertajam terhadap kepekaan perasaan, penalaran, serta kepekaan anak terhadapmasalah kemanusiaan.Kemampuan tersebut ditentukan oleh beberapa faktor penting dalam proses pembelajaran menulis puisi. Selain penerapan model, metode dan strategi yang tepat, juga yang sangat menentukan adalah peranan guru dalam proses pembelajaran terhadap siswa. Hal ini diperkuat oleh Slameto (2003, hlm. 11) mengemukakan metode mengajar dapat mempengaruhi proses belajar. Metode mengajar guru yang kurang baik akan mempengaruhi belajar siswa yang tidak baik pula.

Langkah yang dapat dilakukan untuk meningkatkan kemampuan menulis puisi bebas siswa di kelas V, Peneliti perlu adanya melakukan perbaikan yaitu dengan cara menggunakan model pembelajaran yang dapat memberikan kemampuan siswa menulis puisi sehingga dalam proses pembelajaran lebih menyenangkan.

Berdasarkan observasi awal di lapangan SD Negeri55 Pekanbarumasih terlihat kendala dalam pembelajaran bahasa Indonesia, yaitu berkaitan model pembelajaran menulis puisi. Melihat kondisi di atas, adanya gejala-gejala dalam proses belajar mengajar yaitu: (1) kurangnya keseriusan siswa dalam belajar, hal ini terlihat ketika guru menjelaskan materi pembelajaran siswa kurang antusias, (2)pembelajaran menulis puisi di sekolah dasar sering dilakukan secara menonton dan satu arah (3) siswa mengalami kesulitan dalam menulis puisi sehingga siswa malas dan tidak mau berusaha untuk memikirkan ide-ide yang baru atau cara untuk memunculkan ide (4) siswa bingung menggunakan pilihan kata-kata yang tepat dalam membentuk sebuah puisi. Ketika siswa menulis puisi, peneliti melihat kurangnya kemampuan siswa pada aspek diksi (pilihan kata), pengimajian, tipografi, dan amanat, (5) kurangnya guru membahas secara bersama-sama sehingga siswa tidak mengetahui kekurangan-kekurangan dalam menulis puisi khusunya dalam diksi (pilihan kata) yang tepat, pengimajian, tipografi dan amanat.

Berdasarkan gejala-gejala di atas penulis dapat menganalis bahwa kurangnya keinginan dan kemampuan siswa dalam menulis masih sangat rendah. Kegiatan menulis merupakan pelajaran yang paling sulit di sekolah dasar, serta sulitnya guru memilih teknik, metode, model yang tepat dalam pembelajaran sehingga kurang menarik dan membuat siswa bosan untuk melakukan pada proses pembelajaran. Padahal untuk menulis puisi siswa membutuhkan tuntunan dan arahan yang terstruktur dan mampu menstimulus siswa dengan baik. Model yang digunakan hendaknya mampu mendorong siswa untuk bisa mengungkapkan unsur-unsur pembentukan puisi yang baik seperti penggunaan diksi (pilihan kata), pengimajian, tipografi, dan amanat.

Model sinektik merupakan sebuah model pembelajaran yang dapat mengembangkan dalam proses pembelajaran menulis puisi dan berpikir kreatif yang dimulai dengan mendeskripsikan situasi yang berkaitan dengan visualisasi dan perasaan, penganalogian hingga mampu memeriksa kembali tugas yang telah dilakukannya. Model sinektik ini juga dapat memberikan keleluasaan siswa untuk berpikir secara kreatif yang mengarahkan siswa untuk dapat berpikir melalui alur yang sesuai dengan pola perkembangan anak mulai dari tingkat sekolah 
dasar sampai ketingkat tinggi, pendapat tersebut diperkuat menurut Gordon (Joyce, 2011, hlm. 34) menyatakan bahwa model pembelajaran sinektik ini sangat cocok diterapkan pada pendidikan sekolah dasar (SD) dan sekolah menengah pertama (SMP).

Pendapat di atas sesuai yang diungkapkan oleh Joyce (2011, hlm. 34) menyatakan bahwa model sinektik adalah suatu proses pembelajaran yang dirancang untuk membantu guru memecahkan masalah dan menulis berbagai aktivitas, serta memperoleh prespektif-prespektif baru dalam membuat topik dari berbagai bidang. Sesuai permasalahan di atas maka penulis tertarik melakukan penelitian yang berjudul "Pengaruh ModelPembelajaran SinektikTerhadap Kemampuan Menulis Puisi Bebas Siswa Sekolah Dasar Negeri 55 Pekanbaru.

\section{TINJAUAN TEORITIS}

\section{Pengertian Model Pembelajaran Sinektik}

Model pembelajaran sinektik merupakan sebuah model yang mempertemukan berbagai macam unsur dengan menggunakan kiasan untuk memperoleh suatu pandangan yang baru. Model sinektik berorientasi meningkatkan kemampuan memecahkan masalah, ekspresi kreatif, empati, wawasan dalam hubungan sosial. Sinektik merupakan suatu pendekatan yang menarik guna mengembangkan kreativitas, model sinektik juga bisa digunakan untuk keperluan mengembangkan aktivitas kelompok, setiap individu dilatih untuk bekerjasama dengan yang lainnya dan berfungsi sebagai orang yang mampu mengatasi sebuah masalah.

Pendapat di atas sesuai yang diungkapkan oleh Joyce (2011, hlm. 34) yang menyatakan bahwa model pembelajaran sinektik adalah suatu proses pembelajaran yang dirancang untuk membantu guru memecahkan masalah dan menulis berbagai aktivitas, serta memperoleh prespektif-prespektif baru dalam membuat topik dari berbagai bidang.

Berdasarkan konsep model pembelajaran sinektik, model ini menekankan pada proses penggalian ide-ide yang bermakna guna dapat meningkatkan aktivitas menulis puisi melalui latihan sehingga kreativitas siswa akan berkembang dan dapat dimanfaatkan dalam kehidupan nyata. Gordon juga mengungkapkan bahwa proses spesifik dalam sinektik dikembangkan dari seperangkat anggapan dasar tentang psikologi kreativitas.

Sementara itu menurut shaddiqui (2013, hlm. 132) Model sinektik ini adalah model yang meningkatkankreativitas individu dan kelompok untuk membuat siswa mampubelajar tentang teman sekelas mereka dengan memahami ide-ide dan masalah mereka, untuk mendorongdan mendukung siswa lemah, untuk mengembangkan rasa percaya diri para siswa, untuk mengembangkan kesadaran diri siswa, untukdipakai di semua bidang kurikulum, untuk mendorong diskusi terbaik di antara guru dan siswa, untuk meningkatkan kreativitas siswa dalam menulis khususnya dalam menulis puisi bebas.Untuk mengeksplorasi masalah sosial, untuk mengembangkan pendekatan pemecahan masalah dalam perilakusiswa, untuk membantu siswa untuk membuat desain atau produk, danuntuk memperluas perspektif kita dari konsep.

Berdasarkan definisi di atas, maka penulis dapat menyimpulkanmodel pembelajaran sinektikadalah model pembelajaran yang menekankan pada penggalian ide-ide yang dapat mengubah cara berpikirdengan memberikan wawasan baru dalam berpikir dengan menggunakan analogi yang mereka inginkan sehingga secara tidak langsung siswa dapat berimajinasi dengan menghasilkan sesuatu yang baru, sehingga dapat meningkatkan aktivitas siswa dalam berimajinasi. 


\section{Langkah-langkah Model Sinektik}

Model pembelajaran sinektik memiliki dua jenis strategi dalam pengajaran, pertama dengan menemukan hal-hal yang baru, kedua memperkenalkan keanehan atau keunikan. Penelitian ini mengacu pada konsep strategi pertama karena menurut Gordon (Joyce, 2001, hlm. 222) bahwa strategi pertama lebih menekankan pada suatu penemuan yang baru tetapi bukan memperkenalkan suatu keanehan.

Model pembelajaransinektikdalam penelitian ini memiliki enam tahap yaitu (1) mendeskripsikan situasi saat ini (2) analogi langsung (3) analogi personal (4) konflik padat (5) ana logi langsung (6) memeriksa kembali tugas awal.

\section{Pengertian Menulis}

Menulis merupakan cara untuk berkomunikasi seacara tidak langsung, kegiatan menulis juga merupakan suatu kegiatan dua arah yaitu sebagai penulis sendiri dan juga sebagai pembaca yang dituangkan dalam bentuk grafis atau simbol tulisan yang disusun dalam berbagai teks atau paragraf dan juga bait. Menurut pendapat Tarigan, (2008, hlm. 22) menulis adalah menurunkan atau melukiskan lambang-lambang grafik yang menggambarkan suatu bahasa yang dipahami oleh seseorang, sehingga orang-orang lain dapat membaca lambang-lambang grafik tersebut kalau mereka memahami bahasa dan gambaran grafik tersebut.

Menulis merupakan suatu keterampilan yang digunakan penulis sebagai alat komunikasi secara tidak langsung sehingga seorang penulis melakukan suatu aktivitas dengan melahirkan gagasan, pikiran, perasaan kepada seseorang melalui media berupa tulisan. Dikutip dari Akhadiah (1997, hlm. 89) bahwa menulis adalah suatu bentuk komunikasi secara tidak langsung yang memerlukan proses pemikiran dengan menggunakan ragam bahasa tulis.

Setiap orang memiliki potensi dan kemampuan masing-masing untuk mengungkapkan atau menyampaikan sesuatu dalam bentuk tulisan, walaupun kita ketahui bahwa tidak semua orang memiliki kemampuan untuk menulis. Pendapat yang sama yang yang disampaikan. Karena itu seorang pendidik sangat berperan aktif untuk menggali dan menumbuhkan kepada siswa untuk bisa menulis. Hal ini diungkapkan Semi (2007, hlm 14) bahwasannya hakikat menulis merupakan suatu proses kreatif memindahkan gagasan dalam lambang-lambang tulisan dengan tiga aspek utama dalam tulisan meliputi (1) adanya tujuan dan maksud yang hendak dicapai, (2) adanya gagasan atau suatu yang hendak dikomunikasikan, dan (3) adanya sistem pemindahan gagasan (sistem bahasa).

Berdasarkan pendapat para ahli di atas maka dapat disimpulkan bahwa menulis adalah suatu kegiatan yang komunikasi secara tidak langsung, untuk mengungkapkan, mengekspresikan gagasan atau ide maupun perasaan dengan cara menempatkan simbolsimbol grafis secara tertuls sehingga dapat dipahami oleh seseorang yang membacanya.

\section{Pengertian Puisi}

Puisi merupakan salah satu karya sastra selain prosa dan drama, puisi merupakan salah satu karya sastra yang dipadatkan, dipersingkat. Hakikat puisi sesungguhnya dalam ungkapan perasaan baik itu senang, sedih, kagum, haru, dan lain halnya yang berkaitan dengan perasaan yang dituangkan dalam bentuk tulisan, kemudian orang menuliskannya dalam bentuk bait. Menurut Supriyadi (2006, hlm. 44)Secara etimologi istilah puisi berasal dari bahasa Yunani "poeima" atau "poeisis" yang berarti pembuatan. Sedangkan dalam bahasa Inggris disebut "poem" atau "poetry" yang berarti membuat atau pembuatan, karena lewat puisi pada dasarnya seseorang telah menciptakan suatu dunia tersendiri yang mungkin berisi pesan atau gambaran suasana tertentu, baik fisik maupun batiniah.

Puisi dibentuk oleh beberapa unsur pendukung atau batasan Menurut Waluyo (2010, hlm. 23) memberikan batasan, mendefinisikan puisi adalah Bentuk karya sastra yang mengungkapkan pikiran dan 
perasaan penyair secara imajinatif dan disusun dengan mengonsentrasikan semua kekuatan bahasadengan mengonsentrasikan struktur fisik dan struktur batinnya.

Selanjutnya dikutip dari Maulana (2010, hlm. 21-22) Puisi adalah ungkapan perasaan, semacam nyanyian jiwa yang menyeruak dari kedalaman kalbu sang penyair, apapun nyanyian itu.

Berdasarkan pendapat para ahli tentang pengertian puisi di atas penulis menyimpulkan bahwa puisi adalah suatu karangan atau tulisan yang merupakan ungkapan ekspresi batin, pikiran dan perasaan seseorang tentang halhal yang terjadi di sekitarnya yang dipadu secara padat dan utuh serta mengandung unsur estetika.

\section{Puisi anak di Sekolah Dasar}

Dalam mengajarkan sebuah puisi kepada anak-anak, guru harus terlebih dahulu menyeleksi puisi yang akan diberikan. Tingkatan puisi anak dengan puisi dewasa tidaklah sama. Seorang guru harus mempertimbangkandan memperhatikan puisi apa yang akan diberikan kepada siswa, baik itu dari segi keterbacaan maupun dari segi kesesuaian. Hal ini diperkuat oleh Halik (2009, hlm. 21) ciri dari keterbacan dan kesesuaian yaitu sebagai berikut:

a. Ciri keterbacaan

Pertama,Bahasa yang digunakan dapat dipahami anak. Artinya kosakata yang digunakan dikenal oleh anak, susunan kalimatnya sederhana sehingga dapat dipahami oleh anak.Kedua, pesan yang dikandung puisi dapat dibaca dan dipahami anak karena tidak bersifat tersembunyi melainkan bersifat transparan atau eksplisit.

b. Ciri Kesesuaian

Pertama, Kesesuain dengan kelompok usia anak, anak SD menyukai puisi yang membicarakan kehidupan seharihari, petualangan, kehidupan keluarga yang nyata.Kedua, Kesesuaian dengan lingkungan sekitar tempat anak berada.
Berkaitan hal tersebut, menurut Resmini (2010, hlm. 8) pada dasarnya puisi anak memiliki karakteristik yaitu sebagai berikut:

(1) Bahasanya sederhana, (2) Bentuk naratif, (3) Berisi dimensi kehidupan yang bermakna dan dekat dengan dunia anak, (4) Mengandung unsur bahasa yang indah dengan panduan bunyi pilihan kata dan satua-satuan makna.

Dengan demikian, dalam menulis puisi harus memilih yang sesuai dengan anak sekolah dasar.

\section{METODE PENELITIAN}

Metode penelitian pada penelitian ini menggunakan penelitian kuantitatif. Adapun metode kuantitatif yang digunakan adalah metode eksperimen kuasi atau eksperimen semu yang digunakan untuk mencari pengaruh perlakuan berupa penggunaan modelpembelajaransinektik terhadap kemampuan menulis puisi bebas.

Penelitian ini juga menggunakan statisik deskriptif. Adapun penelitian ini eksperimen kuasi. Penelitian eksperimen kuasi dipandang relevan digunakan, karena memiliki ciri-ciri: a) pemecahan masalah yang aktual, b) data yang dikumpulkan akan disusun, kemudian dijelaskan, dan data tersebut dianalisis. Penelitian menggunakan angka-angka statistik perbandingan antara variabel kontrol dan variabel eksperiman (Sukmadinata, 2013, hlm. 53). Selanjutnya angka-angka tersebut dideskripsikan menggunakan kata-kata, selain itu juga hasil juga dideskripsikan dari karya yang dibuat oleh siswa. Hasil statistiknya dideskripsikan juga dari hasil karya siswa tersebut. Penelitian eksperimen semu banyak digunakan dalam bidang pendidikan atau bidang lain yang subjek penelitiannya tidak dapat di manipulasi dan dikontrol secara intensif (Syamsudin \& Damaianti, 2009, hlm. 23). 


\section{A. Populasi dan Sampel Penelitian}

Populasi yang dijadikan subjek penelitian adalah siswa kelas V SD Negeri 55 Pekanbaru tahun ajaran 2016/2017. Jumlah sampel penelitian berjumlah 60 siswa. 60 siswa tersebut terdiri dari 30 siswa kelas eksperimen dan 30 siswa di kelas kontrol. Di kelas V tersebut kondisi siswa heterogen (berbedabeda kemampuannya). Selain siswa, guru juga menjadi subjek penelitian berkaitan dengan kegiatan guru saat mengajar. Objek penelitiannya adalah kemampuan menulis puisi bebas pada pelajaran bahasa Indonesia.

\section{B. InstrumenPenelitian}

Instrumen penelitian ini adalah tes tulis.Teknik tes adalah siswa harus menulis puisi bertema keindahan alam. Jumlah puisi anak dua bait, perbait kurang lebih 3 sampai 6 baris.

\section{Pelaksanaan Tes}

Tes dalam penelitian ini dilaksanakan dua kali yakni tes tahap awal (pretest) dan tes akhir (posttest).Tujuan tes adalah untuk mengukur kemampuan siswa dengan melihat kemampuan menulis puisi bebassesuai dengan indikator-indikator yang telah ditentukan sebelumnya.

\section{Teknik Pengumpulan Data}

Teknik pengumpulan data merupakan suatu proses yang harus dilaksanakan dalam penelitian guna memperoleh data. Adapun pengumpulan data dalam penelitian ini adalah teknik tes menulis puisi (paper and pencil test) yang dijelaskan sebagai berikut:

a. Teknik Tes

Teknik pengumpulan data yang digunakan oleh peneliti dalam penelitian ini menggunakan tes tertulis. Hal ini diperkuat menurut MacMilan dan Schumacher (2001, hlm. 40) istilah paper and pencil tests diartikan sebagai a standard set of questions is presented to each subject in writing (on paper or computer) that requires completion of cognitive task. Tes tertulis diartikan sebagai seperangkat pertanyaan yang disajikan kepada setiap subyek penelitian dalam bentuk tertulis yang menghendaki penyelesaian tugas kognitif. Tugas kognitif yang dimaksudkan dapat terfokus pada apa yang diketahui seseorang (achievement), kemampuan belajar (ability or aptitude), memilih atau seleksi (interests, attitudes, or value) atau kemampuan mengerjakan sesuatu (skills).

Tes tertulis digunakan sebagai pengumpul data karena bentuk produk dari proses pembelajaran ini adalah karya dalam bentuk puisi, hal tersebut diasumsikan sebagai alat pengumpul data yang efektif.

\section{b. Lembar Observasi}

Lembar observasi digunakan untuk mengamati proses pelaksanaan proses pembelajaran pada saat penelitian. Lembar tersebut mencakup beberapa proses dan aspek pembelajaran yang akan diamati baik dari guru maupun dari siswa. Alat yang digunakan adalah berupa format yang berisi item-item aktivitas siswa dan guru dalam pembelajaran model sinektik dalam proses pembelajaran menulis puisi bebas pada kelas eksperimen.

\section{c. Pedoman Angket}

Angket digunakan untuk mengetahui tanggapan siswa terhadap proses pembelajaran model sinektik dalam pembelajaran menulis puisi bebas. Adapun bentuk pertanyaan yang ada dalam angket tersebut berkaitan dengan komponen-komponen pembelajaran sinektik.

\section{Prosedur Penelitian}

Penelitian ini dilakukan dalam tiga tahap kegiatan yaitu; tahap persiapan penelitian, tahapan penelitian, dan tahapan analisis data. 
1. Tahap Persiapan Penelitian

Tahap ini di awal dengan kegiatan studi kepustakaan mengenai model sinektik untuk memberikan kemampuan menulis puisi bebas selanjutnya menyusun instrumen penelitian yang disertai dengan menyusun instrumen penelitian yang disertai dengan proses bimbingan dari dosen pembimbing dan Jugment(tim ahli).

\section{Tahap Pelaksanaan Penelitian}

Tahap ini, kegiatan awal peneliti memberikan prates di kelas eksperimen dan di kelas kontrol. Hal ini dilakukan untuk mengetahui kemampuan awal siswa dalam kemampuan menulis puisi bebas. Setelah prates dilakukan, kemudian dilanjutkan dengan pembelajaran selama enam kali, kelas eksperimen akan menggunakan model sinektik sedangkan kelas kontrol menggunakan pembelajaran terlangsung. Hal tersebut dilakukan agar adanya perubahan kemampuan menulis puisi bebas.

Setelah dilakukan kegiatan pembelajaran, selanjutnya akan dilakukan pascates pada pertemuan terakhir. Pascates dilakukan bertujuan untuk mengetahui hasil akhir siswa dalam kemampuan menulis puisi bebas. Tahapan analisis data dan pembahasan

Tahapan analisis data menjelaskan secara dekriptif data hasil penelitian, hasil uji statistik kemampuan menulis puisi bebas, uji homogenitas data, uji hipotesis dan pembahasan.

\section{TeknikAnalisis Data}

Teknik pengolahan data dilakukan dengan dua cara yaitu analisis data atau metode deskriptif dan metode statistik. Metode deskriptif digunakan untuk mendeskripsikan data hasil penelitian. Metode statistik digunakan untuk keperluan pengolahan data kuantitatif seperti uji persyaratan data dan uji hipotesis. Setelah hasil statistik didapat selanjutnya dilakukan penarikan kesimpulan untuk untuk ditafsirkan maknanya.Teknik analisis data yang dilakukan. Data-data yang telah dikumpulkan kemudian dianalisis dengan menggunakan program sofewer SPSS.

\section{HASIL PENELITIAN DAN PEMBAHASAN}

Berdasarkan apa yang telah dipaparkan dalam bab sebelumnya, tujuan dari penelitian ini adalah untuk mengkaji, mendeskripsikan, dan membandingkan kemampuan menulis puisi bebas siswa. Peneliti melaksanakan proses pembelajaran dengan model sinektik pada kelas eksperimen dan pembelajaran terlangsung di kelas kontrol. Data di peroleh dari hasil prates dan pascates, kemudian datanya diolah menggunakan program SPSS 18.0 for window, dimana signifikansi $\alpha=0,05$. Adapun analisis data penelitian diarahkan untuk menjawab permasalahan dalam penelitian.

Instrumen yang digunakan dalam penelitian ini adalah tes uraian. Tes tersebut digunakan untuk mengukur kemampuan menulis puisi bebas. Data yang sudah diperoleh, selanjutnya diolah dan dianalisis sesuai dengan rubrik penilaian yang telah ditentukan, sehingga data hasil kemampuan awal (prates) dan kemampuan akhir (pascates) baik itu di kelas eksperimen maupun di kelas kontrol.

\section{DeskripsiPengolahan Data Prates dan Pascates Kemampuan Menulis Puisi Bebas di Kelas Eksperimen dan di Kelas Kontrol}

Hasil prates dan pascates dalam kemampuan menulis puisi bebas di kelas eksperimen menunjukkan hasil yang positif dengan adanya peningkatan nilai rata-rata yang diperoleh pasca pemberian perlakuan. Begitu juga dengan nilai rata-rata hasil prates dan pascates di kelas kontrol menunjukkan peningkatan nilai rata-rata yang diperoleh 
pasca pemberian perlakuan dengan pembelajaran terlangsung.

Hasil prates kemampuan menulis puisi bebas siswa, rata-rata nilai yang diperoleh keseluruhan siswa kelas eksperimen adalah 55,00. Sementara itu, nilai rata-rata kelas kontrol dalam menulis puisi bebas tidak jauh berbeda yakni 54,33.

Selanjutnya, hasil pascates kemampuan menulis puisi bebas siswa kelas eksperimen mengalami peningkatan yang signifikan, rata-rata nilai yang diperoleh keseluruhan siswa kelas eksperimen adalah 71,33. Sementara itu nilai rata-rata kelas kontrol juga mengalami peningkatan yakni 58,66. Berdasarkan tabel deskripsi statistik tersebut peningkatan nilai rata-rata kemampuan menulis di kelas eksperimen lebih tinggi dibandingkan dengan nilai rata-rata kelas kontrol. Dengan demikian, kemampuan menulis puisi bebas siswa kelas eksperimen dapat dilihat peningkatan rata-rata sebesar 12,67 dengan persentase $21,60 \%$.

\section{a. Data Prates Kemampuan Menulis Puisi Bebas Kelas Eksperimen dan Kelas Kontrol}

Kemampuan awal siswa dalam menulis puisi bebas dapat dilihat dari hasil skor prates kelas eksperimen dan kelas kontrol sebelum mengikuti pembelajaran.

Nilai rata-rata tes awal kemampuan menulis puisi bebas kelas eksperimen rataratanya 55,00, sedangkan rata-rata tes awal kemampuan menulis puisi bebas di kelas kontrol adalah 54,33. Selisah rata-rata dari kedua kela tersebut 0,67 dengan persentase perbedaan $0,01 \%$. Dengan demikian antara kelas eksperimen dan kelas kontrol memiliki perbedaan kemampuan awal yang cukup kecil.

Untuk menganalisis skor prates dilakukan uji kesamaan rata-rata prates yang bertujuan untuk melihat apakah kemampuan awal menulis puisi bebas pada kedua kelompok sama atau berbeda secara signifikan. Sebelum data dianalisis terlebih dahulu dilakukan uji prasyarat analisis statistik berikut :

\section{1) Uji Normalitas}

Uji normalitas dilakukan terhadap data prates kemampuan menulis puisi bebas kelas eksperimen dan kelas kontrol. Pengujian ini dilakukan untuk menguji kenormalan distribusi dari populasi penelitian. Uji normalitas data pada penelitian ini menggunakan uji normalitas KolmogorovSmirnov, yakni membandingkan nilai absolut normal kolmogorov-Smirnov dengan nilai pada tabel.

Pasangan hipotesis:

$\mathrm{H}_{0}$ : sampel berasal dari populasi berdistribusi normal

$\mathrm{H}_{1}$ : sampel berasal dari populasi berdistribusi tidak normal

Kriteria pengujian :

Tolak $\mathrm{H}_{0}$ jika $x_{\text {hitung }}^{2}>x^{2}$ tabel

Terima $\mathrm{H}_{0}$ jika $x^{2}{ }_{\text {hitung }}<x_{\text {tabel }}^{2}$

Berdasarkan perhitungan dengan menggunakan uji normalitas KolmogorovSmirnov, untuk data skor prates kelas eksperimen diperoleh $x^{2}{ }_{\text {hitungsebesar }} 0,155$ dengan sampel 30 orang $(n=30)$ pada taraf signifikansi $\alpha=0,05$ diperoleh $x^{2}$ tabel tabel 0,242 . Dengan demikian, ternyata $x^{2}$ hitung $=$ $0,155<x_{\text {tabel }}^{2}=0,242$ maka $\mathrm{H}_{0}$ diterima. Artinya hipotesis diterima, maka kesimpulannya sampel berasal dari populasi yang berdistribusi normal.

Berdasarkan perhitungan dengan menggunakan uji normalitas KolmogorovSmirnov, untuk data skor prates kelas kontrol diperoleh $x^{2}$ hitungsebesar 0,145 dengan sampel 30 orang $(n=30)$ pada taraf signifikansi $\alpha=0,05$ diperoleh $x_{\text {tabel }}^{2}$ tabel 0,242. Dengan demikian, ternyata $x_{\text {hitung }}^{2}=0,145<x_{\text {tabel }}^{2}=0,242$ maka $\mathrm{H}_{0}$ diterima. Artinya hipotesis diterima, maka sampel berasal dari populasi yang berdistribusi normal.

\section{2) Uji Homogenitas}

Setelah uji normalitas, langkah selanjutnya adalah melakukan uji homogenitas, yakni pengujian terhadap besaran variansi dari data 
prates di kelas eksperimen dan di kelas kontrol. Adapun rumus yang digunakan adalah sebagai berikut.

$$
\mathrm{F}=\frac{\text { varian besar }}{\text { varian kecil }}
$$

Pasangan hipotesis:

$\mathrm{H}_{0}$ : sampel memiliki homogenitas yang sama

$\mathrm{H}_{1}$ : sampel tidak memiliki homogenitas yang sama

Karena kedua data berdistribusi normal, maka rumus uji homogenitasnya adalah.

$$
\mathrm{F}=\frac{S_{1}^{2}}{S_{2}^{2}}
$$

Keterangan:

$S_{1}^{2}=$ Varian besar

$S_{2}^{2}=$ Varian Kecil

Kriteria Pengujian:

$\mathrm{H}_{0}$ diterima jika $\mathrm{F}_{(1-\alpha)(\mathrm{n} 1-1)}<\mathrm{F}<\mathrm{F}_{1 / 2 \alpha(\mathrm{n} 1-1)(\mathrm{n} 21)}$

$\mathrm{H}_{1}$ ditolak jika $\mathrm{F} \geq \mathrm{F}_{1 / 2 \alpha(\mathrm{v} 1, \mathrm{v} 2)}$

Sampel prates kelas eksperimen sebanyak 30 orang $\quad\left(\mathrm{n}_{1}=30\right)$ diperoleh varian $\left(s^{2}\right)=12,229^{2}$. Kemudian sampel prates kelas kontrol sebanyak 30 orang $\left(\mathrm{n}_{2}=30\right)$ diperoleh varian $\left(\mathrm{s}^{2}\right)=10,828^{2}$.

Dengan taraf signifikansi $\alpha=0.05$, maka,

$$
\mathrm{F}=\frac{S_{1}^{2}}{S_{2}^{2}}=\frac{12,229^{2}}{10,828^{2}}=1,275
$$

Derajat kebebasan pembilang $=\mathrm{n}-1=30$ $-1=29$, dan derajat kebebasan penyebut $=\mathrm{n}$ $-1=30-1=29$ diperoleh F 0,05 $(29,29)=$ 1,875 .

Dari perhitungan $\mathrm{F}_{\text {hitung }}=1,275$ dan $\mathrm{F}_{\text {tabel }}=$ 1,875

$\mathrm{F}_{\text {hitung }}=1,275<\mathrm{F}_{\text {tabel }}=1,875$, maka $\mathrm{H}_{0}$ diterima. Artinya sampel berasal dari populasi yang homogen.

\section{3) Uji Hipotesis}

Setelah dilakukan uji $\mathrm{t}$ sampel tidak berpasangan dengan menggunakan IBM SPSS
18.0 for windows, diperoleh $\mathrm{t}$ hitung $=0,224$. Derajat kebebasan $(n 1+n 2)-2=(30+30)-2=$ 58 dengan taraf signifikansi $95 \%$ maka $t$ tabel $(0,975)=2,002$. Dengan demikian $\mathrm{t}$ hitung $=$ $0,224<\mathrm{t}_{\text {tabel }}=2,002$. Maka hipotesis hipotesis nol $\left(\mathrm{H}_{0}\right)$ diterima dan hipotesis kerja $\left(\mathrm{H}_{1}\right)$ ditolak.

Kesimpulannya, Terima Hipotesis $\left(\mathrm{H}_{0}\right)$ dan tolak Hipotesis kerja $\left(\mathrm{H}_{1}\right)$ artinya tidak terdapat perbedaan rata-rata kemampuan awal kemampuan menulis puisi bebas siswa kelas eksperimen dengan siswa kelas kontrol. Perbedaan rata-rata ini menunjukkan kemampuan menulis puisi bebas siswa di kelas eksperimen tidak lebih baik dibandingkan dengan kelas kontrol.

\section{b. Data Pascates Kemampuan Menulis Puisi Bebas Kelas Eksperimen dan Kelas Kontrol}

Kemampuan akhir siswa dalam menulis puisi bebas dapat dilihat dari hasil skor pascates kelas eksperimen dan kelas kontrol sesudah mengikuti pembelajaran. Adapun hasil skor pascates kelas eksperimen dan kelas kontrol dapat dipaparkan sebagai berikut.

\section{Tabel 4.6}

Nilai PascatesKemampuan Menulis Puisi Bebas Kelas Eksperimen dan Kelas Kontrol

\begin{tabular}{|c|c|c|c|}
\hline $\begin{array}{c}\text { Pascates } \\
\text { Kelas } \\
\text { Eksperimen }\end{array}$ & $\begin{array}{c}\text { Pascates } \\
\text { Kelas } \\
\text { Kontrol }\end{array}$ & $\begin{array}{c}\text { Selisih } \\
\text { Rata- } \\
\text { rata }\end{array}$ & $\begin{array}{c}\text { Persentase } \\
\text { Perbedaan }\end{array}$ \\
\hline 71,33 & 58,66 & 12,67 & $21,60 \%$ \\
\hline
\end{tabular}

Berdasakan tabel 4.2 dapat diketahui bahwa nilai rata-rata tes akhir kemampuan menulis puisi bebas kelas eksperimen rata-ratanya 71,33. Sedangkan rata-rata tes awal kemampuan menulis puisi bebas di kelas

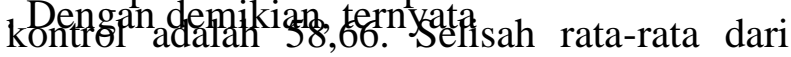
kedua kela tersebut 12,67 dengan persentase perbedaan $21,60 \%$. Dari hasil tersebut, dapat diperoleh peningkatan kemampuan menulis puisi bebas siswa kelas eksperimen tidak sama dengan di kelas kontrol. Nilai rata-rata tes akhir kemampuan menulis puisi bebas antara kelas eksperimen dan kelas kontrol terdapat 
perbedaan kemampuan diantara kedua kelompok tersebut.

Untuk menganalisis skor pascates dilakukan uji kesamaan rata-rata pascates yang bertujuan untuk melihat apakah kemampuan akhir menulis puisi bebas pada kedua kelompok sama atau tidak lebih baik secara signifikan. Sebelum data dianalisis terlebih dahulu dilakukan uji prasyarat analisis statistik berikut.

\section{1) Uji Normalitas}

Uji normalitas dilakukan terhadap data pascates kemampuan menulis puisi bebas kelas eksperimen dan kelas kontrol. Pengujian ini dilakukan untuk menguji kenormalan distribusi dari populasi penelitian. Uji normalitas data pada penelitian ini menggunakan uji normalitas KolmogorovSmirnov, yakni membandingkan nilai absolut normal kolmogorov-Smirnov dengan nilai pada tabel.

Pasangan hipotesis:

$\mathrm{H}_{0}$ : sampel berasal dari populasi berdistribusi normal

$\mathrm{H}_{1}$ : sampel berasal dari populasi berdistribusi tidak normal

Kriteria pengujian :

Tolak $\mathrm{H}_{0}$ jika $x_{\text {hitung }}^{2}>x_{\text {tabel }}^{2}$ dan

Terima $\mathrm{H}_{0}$ jika $x_{\text {hitung }}^{2}<x^{2}$ tabel

Berdasarkan perhitungan di atas perhitungan dengan menggunakan uji normalitas Kolmogorov-Smirnov, untuk data skor pascates kelas eksperimen diperoleh

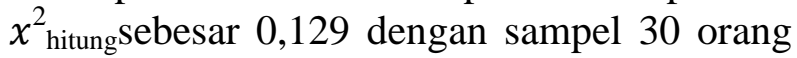
$(\mathrm{n}=30)$ pada taraf signifikansi $\alpha=0,05$ diperoleh $x_{\text {tabel }}^{2}$ tabel 0,242. Dengan demikian, ternyata $x_{\text {hitung }}^{2}=0,129<x_{\text {tabel }}^{2}=0,242{\text { maka } \mathrm{H}_{0}}$ diterima. Artinya hipotesis diterima, maka sampel berasal dari populasi yang berdistribusi normal.

Berdasarkan perhitungan di atas dengan menggunakan uji normalitas KolmogorovSmirnov, untuk data skor prates kelas kontrol diperoleh $x^{2}$ hitungsebesar 0,162 dengan sampel
30 orang $(n=30)$ pada taraf signifikansi $\alpha=0,05$ diperoleh $x_{\text {tabel }}^{2}$ tabel 0,242. Dengan demikian, ternyata $x_{\text {hitung }}^{2}=0,162<x_{\text {tabel }}^{2}=0,242{\text { maka } \mathrm{H}_{0}}^{2}$ diterima. Artinya hipotesis, sampel berasal dari populasi yang berdistribusi normal.

Berdasarkan pemaparan di atas, diketahui bahwa seluruh data kemampuan menulis puisi bebas sampel penelitian berdistribusi normal, artinya telah memenuhi syarat untuk pengujian tahap selanjutnya.

\section{2) Uji Homogenitas}

Pasca uji normalitas, langkah selanjutnya adalah melakukan uji homogenitas, yakni pengujian terhadap besaran variansi dari data pascates di kelas eksperimen dan kelas kontrol. Adapun rumus yang digunakan adalah:

$$
\mathrm{F}=\frac{\text { varian besar }}{\text { varian kecil }}
$$

Pasangan hipotesis:

$\mathrm{H}_{0}$ : sampel memiliki homogenitas yang sama

$\mathrm{H}_{1}$ : sampel tidak memiliki homogenitas yang sama

Karena kedua data berdistribusi normal, maka rumus uji homogenitasnya adalah

$$
\mathrm{F}=\frac{S_{1}^{2}}{S_{2}^{2}}
$$

Keterangan:

$S_{1}^{2}=$ Varian besar

$S_{2}^{2}=$ Varian Kecil

Kriteria Pengujian:

$\mathrm{H}_{0}$ diterima jika $\mathrm{F}_{(1-\alpha)(n 1-1)}<\mathrm{F}<\mathrm{F}_{1 / 2 \alpha(n 1-1)(n 2-1)}$ $\mathrm{H}_{1}$ ditolak jika $\mathrm{F} \geq \mathrm{F}_{1 / 2 \alpha(\mathrm{v} 1, \mathrm{v} 2)}$

Sampel pascateskelas eksperimen sebanyak 30 orang $\left(\mathrm{n}_{1}=30\right)$ diperoleh varian $\left(\mathrm{s}^{2}\right)=10,694^{2}$. Kemudian sampel pascateskelas kontrol sebanyak 30 orang $\left(\mathrm{n}_{2}=30\right)$ diperoleh varian $\left(\mathrm{s}^{2}\right)=10,499^{2}$.

Dengan taraf signifikansi $\alpha=0.05$, maka,

$$
\mathrm{F}=\frac{S_{1}^{2}}{S_{2}^{2}}=\frac{10,694^{2}}{10,499^{2}}=1,0374
$$


Derajat kebebasan pembilang $=\mathrm{n}-1=31$ $-1=30$, dan derajat kebebasan penyebut $=n$ $-1=30-1=30$ diperoleh F $0,05(29,29)=$ 1,875.Dari perhitungan $\mathrm{F}_{\text {hitung }}=1,0374$ dan $\mathrm{F}$ tabel $=1,875$ dengan demikian, ternyata $\mathrm{F}$ hitung $=1,0374<\mathrm{F}$ tabel $=1,875$, maka $\mathrm{H}_{0}$ diterima. Artinya sampel berasal dari populasi yang homogen.

\section{3) Uji Perbedaan}

Setelah dilakukan uji $\mathrm{t}$ sampel tidak berpasangan dengan menggunakan IBM SPSS 18.0 for windows, diperoleh $\mathrm{t}_{\text {hitung }}=4,75$.

Derajat kebebasan $(n 1+n 2)-2=(30+30)-$ $2=58$ dengan taraf signifikansi $95 \%$ maka $t$ tabel $(0,975)=2,002$. Dengan demikian $\mathrm{t}_{\text {hitung }}=$ 4,75> $\mathrm{t}$ tabel $(0,975)=2,002 . \mathrm{H}_{0}$ ditolak dan $\mathrm{H}_{1}$ diterima.

Kesimpulannya, Tolak Hipotesis $\left(\mathrm{H}_{0}\right)$ dan terima Hipotesis kerja $\left(\mathrm{H}_{1}\right)$ artinya terdapat perbedaan rata-rata kemampuanakhir menulis puisi bebas siswa kelas eksperimen dengan siswa kelas kontrol dalam kemampuan menulis puisi bebas. Perbedaan rata-rata ini menunjukkan bahwa terdapat pengaruh model pembelajaran sinektik terhadap kemampuan akhir menulis puisi bebas di kelas eksperimen.

Berdasarkan pemaparan antara kelas eksperimen dan kelas kontrol, dari uji t data prates diketahui bahwa tidak terdapat perbedaan nilai rata-rata menulis puisi bebas antara siswa kelas eksperimen dengan kelas kontrol. Kemudian dari uji t data pascates, diketahui bahwa terdapat perbedaan nilai ratarata menulis puisi bebas antara siswa kelas eksperimen dengan kelas kontrol. Berdasarkan hasil uji $\mathrm{t}$ prates dan pascates terdapat pengaruh model pembelajaran sinektik terhadap kemampuan menulis puisi bebas di kelas eksperimen.

\section{Pembahasan}

Penelitian ini dilaksanakan salah satu SD Negeri 55 Pekanbaru. Pelaksanaan penelitian ini membutuhkan waktu selama satu bulan, dari bulan Mei sampai bulan April. Penelitian berlangsung 8 kali pertemuan. Pertemuan pertama seluruh siswa diberi prates kemampuan menulis puisi bebas baik itu di kelas di kelas eksperimen maupun di kelas kontrol.

Berdasarkan hasil Prates kemampuan menulis puisi bebas di kelas eksperimen dan kelas kontrol ditemukan bahwa kemampuan kedua kelas tersebut hampir sama. Hal ini dapat dilihat dari rata-rata nilai prates kemampuan kelas eksperimen sebesar 55.00 dan rata-rata kelas kontrol sebesar 54.33. Setelah melaksanakan prates untuk kedua kemampuan tersebut, kemudian diberikan perlakuan sebanyak enam kali pertemuan. Perlakuan pembelajaran di kelas eksperimen dengan menggunakan model sinektik. Dalam pembelajaran menggunakan sinektik ini, guru berusaha mengembangkan kreativitas siswa dengan cara siswa dapat mengungkapkan gagasan atau idenya dengan arahan yang diberikan guru sesuai dengan langkah-langkah pembelajaran sinektik.

Dikutip dari Gordon (dalam Shaddiqui2013, hlm.132) mengatakan bahwa "model sinektik ini adalah model yang meningkatkankreativitas individu dan kelompokuntuk membuat siswa mampubelajar tentang teman sekelas mereka dengan memahami ide-ide dan masalah mereka, untuk mendorongdan mendukung siswa lemah, untuk mengembangkan rasa percaya diri para siswa, untuk mengembangkan kesadaran diri siswa, untukdipakai disemua bidang kurikulum, untuk mendorong diskusi terbaik di antara guru dan siswa, untuk meningkatkan kreativitas, untuk mengeksplorasi masalah sosial, untuk mengembangkan pendekatan pemecahan masalah dalam perilakusiswa, untuk membantu siswa untuk membuat produk, danuntuk memperluas perspektif kita dari konsep.

Berdasarkan kajian teori yang telah dipaparkan pada bab sebelumnya, Penelitian ini untuk melihat pengaruh pembelajaran dengan menggunakan model sinektik terhadap kemampuan menulis puisi bebas. Adapun model ini digunakan peneliti di kelas 
eksperimen. Sedangkan di kelas kontrol menggunakan pembelajaran terlangsung.

Pembelajaran menggunakan model sinektik, hal ini telah dipaparkann menurut dari Joyce (2010, hlm. 258). Model sinektikdalam penelitian ini memiliki enam tahap yaitu (1) mendeskripsikan situasi saat ini (2) analogi langsung (3) analogi personal (4) konflik padat (5) analogi langsung (6) memeriksa kembali tugas awal.

Berdasarkan langkah-langkah tersebut siswa dapat belajar menemukan gagasangagasan atau ide dari gambaran situasi tema atau topik yang telah diberikan guru (mendeskripsikan situasi saat ini), siswa memberikan analogi-analogi langsung yang dilihatnya dan menganalogikan atau menganggap dirinya sebagai objek atau sebuah benda, hewan, tumbuhan, dan sesuatu yang mereka lihat dan mereka sukai kemudian siswa mengembangkannya menjadi beberapa kerangka baris (ananlogi langsung), siswa menentukan analogi personal yang dimaksudkan dalam tahapan ini siswa menjadi sesuatu objek atau benda yang mereka sukai dan telah mereka pilih dalam tahapan kedua (analogi personal).

Kemudian Siswa menuliskan gagasan secara tepat sehingga mereka dapat membuat sebuah konsep puisi yang akan mereka tulis dengan bantuan guru dan bantuan satu dengan yang lainnya. Siswa memunculkan beberapa analogi konflik padat dan memilih salah satunya. Misalnya siswa berimajinasi tentang sebuah bunga yang indah, wangi, dan cantik yang kemudian dimunculkan konflik padatnya kemudian ditulis dalam bentuk sebuah karya.

Siswa menulis analogi langsung yang lain yang didasarkan pada analogi konflik padat (analogi langsung), kemudian siswa menganalogikan satu konsep siswa juga menganalogikan konsep yang lain contoh selain siswa menganalogikan bunga, siswa juga menganologikan keindahan yang lain misalnya seperti sungai. Selanjutnya siswa mengembangkannya berdasarkan kemampuan. Kemudian siswa kembali pada suatu permasalahan awal dan menggunakan analogi terakhir yang akan dijadikan sebagai pengalaman sinektiknya, kemudian dibuat dalam tulisan yang bentuk puisi.

Selanjutnya dilakukan pascates pada pertemuan terakhir, pascates dilakukan tujuannya untuk mengetahui pengaruh model sinektik terhadap kemampuan akhir.

Berdasarkan uji hipotesis kemampuan menulis puisi di kelas eksperimen diperoleh nilai $t_{\text {hitung }}$ sebesar 4,751 dan $t_{\text {tabel }}$ dengan taraf signifikansi $\alpha=0.05$ diperoleh $(2,002)$. Dari nilai tersebut diperoleh nilai $t_{\text {hitung }}$ lebih besar dari $t_{\text {tabel. }}$. Hal ini diinterpretasikan bahwa $\mathrm{H}_{0}$ ditolak yang memiliki makna bahwa terdapat perbedaan rata-rata kemampuan menulis puisi bebas antara kelas eksperimen dan kelas kontrol. Perbedaan rata-rata ini menunjukkan terdapat pengaruh model pembelajaran sinektik terhadap kemampuan menulis puisi di kelas eksperimen. Perbedaan ini dapat dilihat dari rata-rata pascates kemampuan menulis puisi bebas kelas eksperimen terdapat perbedaan untuk kemampuan menulis puisi bebas di kelas eksperimen 71.33 dan rata-rata di kelas kontrol sebesar 58.66. Berdasarkan uji hipotesis kemampuan menulis puisi bebas didapatkan bahwa model sinektik berpengaruh signifikan terhadap kemampuan menulis puisi bebas.

\section{SIMPULAN}

Berdasarkan hasil penelitian dan pembahasan yang telah dikemukakan pada pada bab sebelumnya, bahwa kemampuan menulis puisi bebas yang menggunakan model pembelajaran sinektik lebih baik daripada menggunakan pembelajaran terlangsung. Materi yang diberikan adalah bentuk soal uraian yaitu siswa menulis sebuah puisi bebas. Dengan demikian, dapat mengetahui kemampuan siswa dalam menulis sebuah puisi dengan menggunakan model pembelajaran sinektik.

Berdasarkan hasil yang telah didapatkan dari prates dan pascates, peneliti 
dapat menarik simpulan yaitu: secara empirik, hasil penelitian yang berdasarkan kajian teori yang mendukung dan pembahasan yang sudah dipaparkan pada bab sebelumnya, maka model pembelajaransinektik berpengaruh terhadap kemampuan menulis puisi bebas di kelas eksperimen. Hal ini dapat dilihat dari hasil uji perbedaan rerata kemampuan menulis puisi bebas yang menunjukkan bahwa nilai $t_{\text {hitung }}$ 4,751 lebih besar dari $t_{\text {tabel }}$ dengan taraf signifikansi $\alpha=0,05(2,002)$ yang memiliki makna $\mathrm{H}_{0}$ ditolak yang memiliki makna bahwa terdapat perbedaan rerata kedua kelas tersebut atau dengan kata lain model pembelajaransinektik terdapat pengaruh terhadap kemampuan menulis pusi bebas antara kelas eksperimen dan kelas kontrol. Hasil uji hipotesis ini bisa didukung dengan peningkatan rata-rata antara prates dan pascates kemampuan menulis puisi bebas sebesar 29,69\%. Pengaruh peningkatan tersebut dapat terjadi karena komponenkomponen model sinektik mendukung dan selaras dalam aktivitas menulis puisi bebas.

\section{DAFTAR PUSTAKA}

Aep, S. (2013). Keefektifan model sinektik berorientasi berpikir imajinatif dalam pembelajaran menulis puisi. Tesis,Sekolah Pascasarjana, Universitas Pendidikan Indonesia.

Aminuddin. (2013). Pengantar apresiasi karya sastra. Bandung: Sinar Baru Algensindo.

Arikunto, S. (2013). Dasar-dasar evaluasi pendidikan (edisi kedua). Jakarta: Bumi Aksara.

Arsyad, A. (2010). Media pembelajaran. Jakarta: PT. Raja Grafindo Persada.

Halik. A. (2009). Sastra anak-anak. Jakarta: Depdiknas.
Haryadi dan Zamzani. (2005). Peningkatkan keterampilan berbahasa indonesia. Yogyakarta:

Departemen Pendidikan.

Joyce, Bruce.,dkk. (2009). Models of teaching. New Jersey: Pearson Education Inc.

Kokom, K. (2013). Pembelajaran kontekstual konsep dan aplikasi. Bandung: PT Refika Aditama..

Sugiyono. (2008). Metode penelitian pendidikan. Bandung: PT Alfabeta.

Syamsuddin, A. R dan Damaianti, V. (2011). Metode penelitian pendidikan bahasa. Bandung: PT Remaja Rosdakarya.

Mitchell, D. (2003). Children's literature, an invitation to the world. Boston: Ablongman.

Musthafa, B. (2013) Literasi dini dan literasi remaja: Teori, Konsep, dan Praktik. Bandung: Crest.

Ningsih, S, dkk. (2007). Bahasa Indonesia. Yogyakarta : Andi.

Nurgiyantoro, B. (2009). Penilaian dalam pembelajaran bahasa indonesia SD. Yogyakarta: BPFE-Yogyakarta.

Purwanto, N. (1991). Prinsip-prinsip dan teknik evaluasi pengajaran. Bandung: Remaja Rosdakarya.

Resmini, N. (2010). Sastra anak dan pengajarannya. Bandung:UPI.

Sadiman, A. S, dkk. (2006). Media pendidikan. Jakarta: PT Raja Grafindo Persada. 
Semi, A. (2007). Dasar-dasar keterampilan menulis. Bandung: Angkasa.

Slameto. 2003. Evaluasi pendidikan. Jakarta:

Bumi Aksara.

Sudjana, N. (2013). Penilaian hasil proses belajar mengajar. Bandung: Remja Rosdakarya.

Supriyadi. (2006). Pembelajaran sastra yang apresiatif dan integratif di sekolah Dasar. Jakarta: Departemen Pendidikan.

Sumarmo, dkk.(2009). Pembelajaran menulis. Jakarta: Depdiknas.

Syarif, E, dkk. (2009). Pembelajaran menulis. Jakarta: Depdiknas.

Tarigan, H. G. (2008). Menulis sebagai suatu keterampilan berbahasa. Bandung: Percetakan Angkasa.

Waluyo, H . J. (2010). Teori dan apresiasi membaca puisi. Jakarta: Erlangga. 